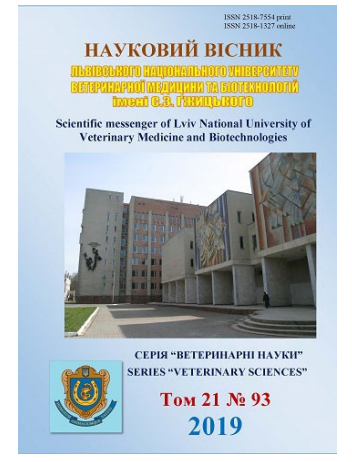

Науковий вісник Дьвівського національного університету ветеринарної медицини та біотехнологій імені С.3. Гжицького.

\author{
Серія: Ветеринарні науки
}

Scientific Messenger of Lviv National University of Veterinary Medicine and Biotechnologies. Series: Veterinary sciences

\title{
PCR-test for identification and species differentiation of Waddlia chondrophila
}

\author{
V.K. Zezekalo ${ }^{1}$, S.B. Pedera ${ }^{1}$, T.V. Buslik², K.F. Pochernyaev ${ }^{2}$ \\ ${ }^{1}$ Poltava State Agrarian Academy, Poltava, Ukraine \\ ${ }^{2}$ Institute of pig breeding and agroindustrial production National Academy of Agricultural Science of Ukraine, Poltava, \\ Ukraine
}

Article info

Received 12.02.2019

Received in revised form 13.03.2019

Accepted 14.03.2019

Poltava State Agrarian Academy, Skovorody Str., 1/3, Poltava, 36003, Ukraine.

Tel.: +38-095-645-56-26

E-mail:v.zezekalo@gmail.com

Institute of pig breeding and agroindustrial production National Academy of Agricultural Science of Ukraine, Shvedska Mohyla 1, Poltava, 36013, Ukraine.
Zezekalo, V.K., Pedera, S.B., Buslik, T.V., \& Pochernyaev, K.F. (2019). Pcr-test for identification and species differentiation of Waddlia chondrophila. Scientific Messenger of Lviv National University of Veterinary Medicine and Biotechnologies. Series: Veterinary sciences, 21(93), 143148. doi: $10.32718 /$ nvlvet 9325

In recent times, the number of species of chlamydia associated with a number of inflammatory diseases in animals has expanded considerably. Moreover, in addition to chlamydia, attention was attracted by Chlamydia-like organisms, which are not only dangerous for animals, but also carry a zoonotic threat. Currently, the most studied Chlamydia-like organisms are Waddlia chondrophila and Parachlamydia acanthamoebae. They are associated with diseases of the reproductive and respiratory systems in cattle and humans. Considering the danger to animals and the zoonotic threat of chlamydia-like organisms along with the absence of tools to discover them in Ukraine, the aim of our work was to develop a PCR test for the identification and species differentiation of Waddlia chondrophila. Conservative $16 S$ rRNA genes were chosen as target genes for developing a PCR test system for identifying Waddlia chondrophila. Primers were selected specifically to be able to create multiplex combinations with the previously developed PCR test for Parachlamydia acanthamoebae. Both primers were designed with the same physical characteristics to provide simultaneous amplification under the same conditions in single or multiplex PCR. For the specificity evaluation of the primers, a panel of following DNA samples was used: Waddlia chondrophila, Parachlamydia acanthamoebae, Chlamydia avium, Chlamydia pecorum, Chlamydia abortus, Chlamydia psittaci, Chlamydia suis, Chlamydia caviae, Clavochlamydia salmonicola, Piscichlamydia salmonis. PCR product of 88 base pairs (b.p.) was formed during amplification only when the Waddlia chondrophila control DNA was present in the sample, as was expected. The small size of the PCR product theoretically allows the use of this pair of oligonucleotide primers for real-time PCR tests. After testing on clinical samples, developed PCR test system for identifying and species differentiation of Waddlia chondrophila can be used by scientists for extensive monitoring, by veterinary medicine doctors to clarify the diagnosis, and might be introduced into the practice of laboratories of veterinary and humane medicine.

Key words: Waddlia chondrophila, primers, chlamydia, zoonoses, PCR, Chlamydia-like organisms, Chlamydia-related bacteria.

\section{ПЛР-тест для ідентифікації та видової диференціації Waddlia chondrophila}

\author{
В.К. Зезекало ${ }^{1}$, С.Б. Передера ${ }^{1}$, Т.В. Буслик ${ }^{2}$ К.Ф. Почерняєв ${ }^{2}$ \\ ${ }^{1}$ Полтавська державна аграрна академія, м. Полтава, Україна \\ ${ }^{2}$ Інститут свинарства і агропромислового виробництва НААН, м. Полтава, Україна
}

Останнім часом кількість видів хламідій, пов'язаних з рядом запальних захворювань тварин, значно розщилась. Більи того, окрім хламідій, увагу привернули хламідіє-подібні організми, які не тільки є небезпечними для тварин, але й несуть зоонозну загрозу. Найбільш вивченими, на даний момент хламідіє-спорідненими організмами є Waddlia chondrophila ma Parachlamydia acanthaтоеbае, їх пов'язують з захворюваннями репродуктивної та респіраторної систем великої рогатої худоби та людини. 3 огляду 
на небезпечність для тварин і зоонозну загрозу хламідіє-подібних організмів та відсутністю доступного способу їх дослідження метою нашої роботи стало розроблення ПЛР - тесту для ідентифікації і видової диференціації Waddlia chondrophila. При розробиі ПЛР - тест система для виявлення Waddlia chondrophila в якості генів-мішеней були обрані консервативні гени 16S рРНК. Праймери підбиралися таким чином, щоб була можливість створення мультиплексних поєднань з раніше розробленою нами ПЛРтест-системою з Parachlamydia acanthamoеbaе. Ці праймери були розроблені з однаковими фізичними характеристиками, щзоб мати можливість забезпечити одночасну ампліфікацію в однакових умовах в одиночних або мультиплексних ПЛР. Для очінки специффічності праймерів використовувалася панель зразків ДНК: Waddlia chondrophila, Parachlamydia acanthamoеbae, Chlamydia avium, Chlamydia pecorum, Chlamydia abortus, Chlamydia psittaci, Chlamydia suis, Chlamydia caviae, Clavochlamydia salmonicola, Piscichlamydia salmonis. Праймери давали продукт ПЛР 123 пари нуклеотидів (п.н.) тільки тоді, коли у зразку була присутня контрольна ДНК Waddlia chondrophila, як і очікувалося. Незначний розмір ПЛР-продукту теоретично дозволяє використовувати дану пару олігонуклеотидних праймерів і для ПЛР-тестів в реальному часі. Розроблена ПЛР тест-система для ідентифікації та видової диференціачї Waddlia chondrophila після апробаџї̈ на клінічному матеріалі може бути використана вченими для иирокого моніторингу, використовуватись лікарями ветеринарної медицини для уточнення діагнозу, бути введеними в практику лабораторій ветеринарної медицини та гуманної медицини.

Ключові слова: Waddlia chondrophila, праймери, хламідіози, зоонози, ПЛР, хламідієподібні бактерії.

\section{Вступ}

Представники порядку Chlamydiales поширені в усьому світі, вони викликають широкий діапазон захворювань у більш ніж 400 видів тварин та людини. Хламідійні інфекції можуть протікати безсимптомно, після лікування можливе тривале хламідієносійство (Ks'onz, 2012; Burnard \& Polkinghorne, 2016).

В останні роки, значно розшилась кількість видів хламідій пов'язаних 3 рядом запальних захворювань тварин, включаючи артрити, кон'юнктивіти, пневмонії і аборти. Більш того, окрім хламідій, увагу привернули хламідіє-подібні організми, які не тільки є небезпечними для тварин, але й несуть зоонозну загрозу (Taylor-Brown et al., 2015). До порядку Chlamydiales тепер належать 9 родин (Chlamydiaceae, Waddliaceae, Parachlamydiaceae, Criblamydiaceae, Simkaniaceae, Ca. Clavochlamydiaceae, Ca. Rhabdochlamydiaceae, Ca.
Piscichlamydia, Ca. Parilichlamydiaceae). Добре відома всім родина Chlamydiaceae, зараз складається 314 видів (Chlamydia abortus, Chlamydia avium, Chlamydia caviae, Chlamydia felis, Chlamydia gallinacea, Chlamydia muridarum, Chlamydia pecorum, Chlamydia pneumoniae, Chlamydia psittaci, Chlamydia suis, Chlamydia trachomatis, Candidatus Chlamydia ibidis, Candidatus Chlamydia sanzinia, Candidatus Chlamydia corallus), об'єднаних в рід Chlamydia. Родини: Waddliaceae, Parachlamydiaceae, Criblamydiaceae, Simkaniaceae, Ca. Clavochlamydiaceae, Ca. Rhabdochlamydiaceae, Ca. Piscichlamydia, Ca. Parilichlamydiaceae 3 їх численними представниками називають хламідієспорідненими бактеріями, або хламідіє-подібними організмами, через їх генетичну та фенотипову подібність, та філогенетичну відокремленість від родини Chlamydiaceae, рис. 1 (Zezekalo et al., 2019).

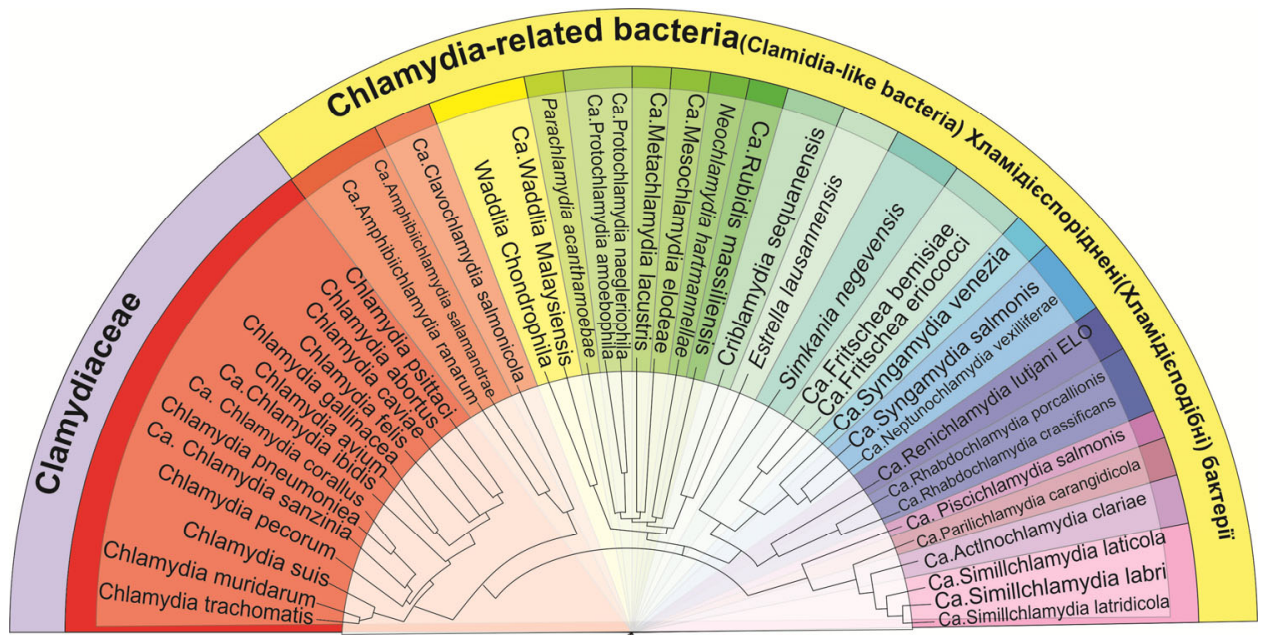

Рис.1. Таксономічна класифікація 2018 р. Сформовано на основі (Zezekalo et al., 2019)

Щодо хламідіє-подібних організмів, патогенних для сільськогосподарських тварин, то до них слід віднести найбільш відомих і вивчених на даний момент - Waddlia chondrophila та Parachlamydia acanthamoebae.

Вперше Waddlia chondrophila була виділена 3 аборт-плоду великої рогатої худоби у США в 1990 році (Dilbeck et al., 1990). Dilbeck P.M. et al., був підтверджений зв'язок між антитілами проти Waddlia chondrophila і абортами великої рогатої худоби. Більш того, 1 з 2 телят, які були експериментально інфіковані $W$. chondrophila, померло протягом 2 тижнів (Dilbeck-Robertson et al., 2003). Патогенна роль $W$. chondrophila у людини підтверджується сильною асоціацією між серопозитивністю W.chondrophila i викиднем людини (Baud et al., 2011). 
Крім того, W. chondrophila виявлена у респіраторних зразках хворих на бронхіоліт або пневмонію людей (Haider et al., 2008; Goy et al., 2009).

Parachlamydia acanthamoebae згадується в численних публікаціях в зв'язку абортами, пневмоніями, респіраторними захворюваннями ВРX та людини (Corsaro et al., 2002; Greub et al., 2003; Borel et al., 2007; Barkallah et al., 2014).

3 огляду на небезпечність для тварин і зоонозну загрозу хламідіє-подібних організмів та відсутністю доступного способу їх дослідження метою нашої роботи стало розроблення ПЛР - тесту для ідентифікації і видової диференціації Waddlia chondrophila.

\section{Матеріал і методи досліджень}

Зразки контрольних ДНК Parachlamydia acanthamoebae штами - "Berg17" та "Вn9” люб'язно надані Dr. Michel Rolf (Central Military Hospital Koblenz, Germany, Dept. Pathology), ДНК Parachlamydia acanthamoebae штам Нall одержані від Prof. Gilbert GREUB (l'Institut de Microbiologie Médecin chef des laboratoires de microbiologie diagnostique Institut de microbiologie de l'Université de Lausanne), зразки ДНК Waddlia chondrophila, Chlamydia avium, Chlamydia pecorum, Chlamydia abortus, Chlamydia psittaci, Chlamydia suis, Chlamydia caviae були отримані від Dr. Christiane Schnee (Institut für molekulare Pathogenese, Jena, Germany), зразки Clavochlamydia salmonicola та Piscichlamydia salmonis отримано від Dr med vet, Dipl. ECVP, Heike Schmidt-Posthaus, (Centre for Fish and Wildlife Health Bern). Зразки контрольних ДНК використовувались для апробації і перевірки аналітичної специфічності розроблених ПЛР-тест-систем.

Біоінформаційні дослідження проводили шляхом вирівнювання 111 первинних нуклеотидних послідовностей генів, що кодують $16 \mathrm{~S}$ rRNA за допомогою програми “MEGA7”. Для конструювання специфічних праймерів обиралися найбільш варіабельні (поліморфні) ділянки. Означені первинні нуклеотидні послідовності отримували із світових баз даних "NCBI". Дизайн олігонуклеотидних праймерів розробляли на основі визначених поліморфних ділянок, за допомогою онлайн-сервісу Primer-BLAST. Primer-BLAST використовувався для оцінки критичних параметрів праймера, зокрема, температури плавлення, різниці температур плавлення для пар праймерів, GC- складу, самокомплементарності тощо.

Розроблені олігонуклеотидні праймери 3 прийнятними фізико-хімічними параметрами були перевірені на відсутність комплементарності з нуклеотидними послідовностями інших мікроорганізмів за допомогою веб-додатку "Blast".

ПЛР. Дослідження проводились на базі лабораторій здоров'я тварин та генетики Інституту свинарства та АПВ НААН, що сертифікована для проведення генетичного аналізу на рівні ДНК (Свідоцтво про відповідність стану системи вимірювань № 021-19 від 31.01.2019 p).
Ампліфікацію ДНК виконували з використанням реагентів "Thermo Fisher Scientific" за умовами виробника. Олігонуклеотидні праймери для ідентифікації Waddlia chondrophila прямий WADCHOF: GAACGAAGTGTGCTCTTGAGT та зворотній WADCHOR:CCTCTCTAGCACCATATCCGG, що фланкують фрагмент ділянки ДНК гену $16 \mathrm{~S}$ рРНК, розміром 123 пари нуклеотидів (п.н.) було синтезовано (Metabion international AG, ФРН).

Ампліфікацію ДНК за допомогою ПЛР проводили на програмованому термостаті ТЕРЦИК-2 (ДНКТехнологии, РФ) за температури відпалу $60{ }^{\circ} \mathrm{C}$. Продукти ПЛР розділяли за допомогою $2 \%$ агарозного гель-електрофорезу у $1 \times$ Трис-боратному електродному буфері (TBE) упродовж 2 год за сили струму 50 мА в електрофоретичній камері (Cleaver Scientific Ltd. UK). Як маркер молекулярної маси використовували ДНК плазміди $p U C 19$, гідролізованої ендонуклеазою $M s p$ I. Після закінчення електрофорезу гель фарбували розчином бромистого етидію $\left(10 \mathrm{Mг} / \mathrm{cm}^{3}\right)$ та фотографували за допомогою системи гельдокументації (Cleaver Scientific Ltd. UK).

\section{Результати та їх обговорення}

ПЛР діагностика хламідійних інфекцій, яка була б доступною для рутинного клінічного використання, i $\epsilon$ найкращим і рекомендованим методом для виявлення хламідійних інфекцій. Більш висока чутливість ПЛР діагностикумів $є$ їх основною перевагою в порівнянні з культуральними методами та іншими некультурними методами (наприклад, імуноферментним аналізом, серологічними методами та ін.), які бувають надто трудомісткі, складні у виконанні і іноді безрезультатні (Blumer et al., 2011).

Незважаючи на значення цих збудників для ветеринарної і гуманної медицини та їх зоонозного потенціалу, на сьогодні в Україні не існувало таких тестсистем, які б могли виявити i диференціювати Waddlia chondrophila.

Незважаючи на значення цих збудників для ветеринарної і гуманної медицини та їх зоонозного потенціалу, на сьогодні в Україні не існувало таких тестсистем, які б могли виявити i диференціювати Waddlia chondrophila.

При розробці ПЛР-тест системи для виявлення Waddlia chondrophila в якості генів-мішеней були обрані консервативні гени 16S pPHК, для яких сконструйовані (підібрані) відповідні праймери. Праймери підбиралися таким чином, щоб була можливість створення мультиплексних поєднань 3 раніше розробленою нами ПЛР-тест-системою 3 Parachlamydia acanthamoebae прямий PCHAF: CAAGGTAGCCCTATCGGAAG та зворотний PCHAR:CTTGCCCAACCTCGGAAGAT, що фланкують фрагмент ділянки ДНК гену $16 \mathrm{~S}$ р PHК, розміром 88 пар нуклеотидів (п.н.) (Zezekalo et al., 2018). Ці праймери були розроблені з однаковими фізичними характеристиками, щоб мати можливість забезпечити одночасну ампліфікацію в однакових умовах в одино- 
чних або мультиплексних ПЛР. Пари праймерів Waddlia chondrophila i Parachlamydia acanthamoebae різняться довжиною ампліконів, розрив цільового фрагмента перевищує 30 п.н., щоб задовольнити вимоги розподільної здатності для електрофорезу в $2 \%$ агарозному гелі. Довжина праймерів становить від 20 до 21 пар основ, а їх температури плавлення $-60{ }^{\circ} \mathrm{C}$. Така довжина і температура відпалу дають менше неспецифічних продуктів.
Ключовим кроком у створенні праймерів було знаходження найбільш варіабельних ділянок всередині кожної з послідовностей ДНК гену $16 \mathrm{~S}$ рPНК i використання цих ділянок в якості видоспецифічних ділянок. Для оптимізації ПЛР виявлення Waddlia chondrophila та Parachlamydia acanthamoebae було виконано тестування температури відпалу в діапазоні від 55 до $63{ }^{\circ} \mathrm{C}$. Оптимальна температура становила $60{ }^{\circ} \mathrm{C}$ при стандартних концентраціях компонентів ПЛР (рис. 2 а, б).

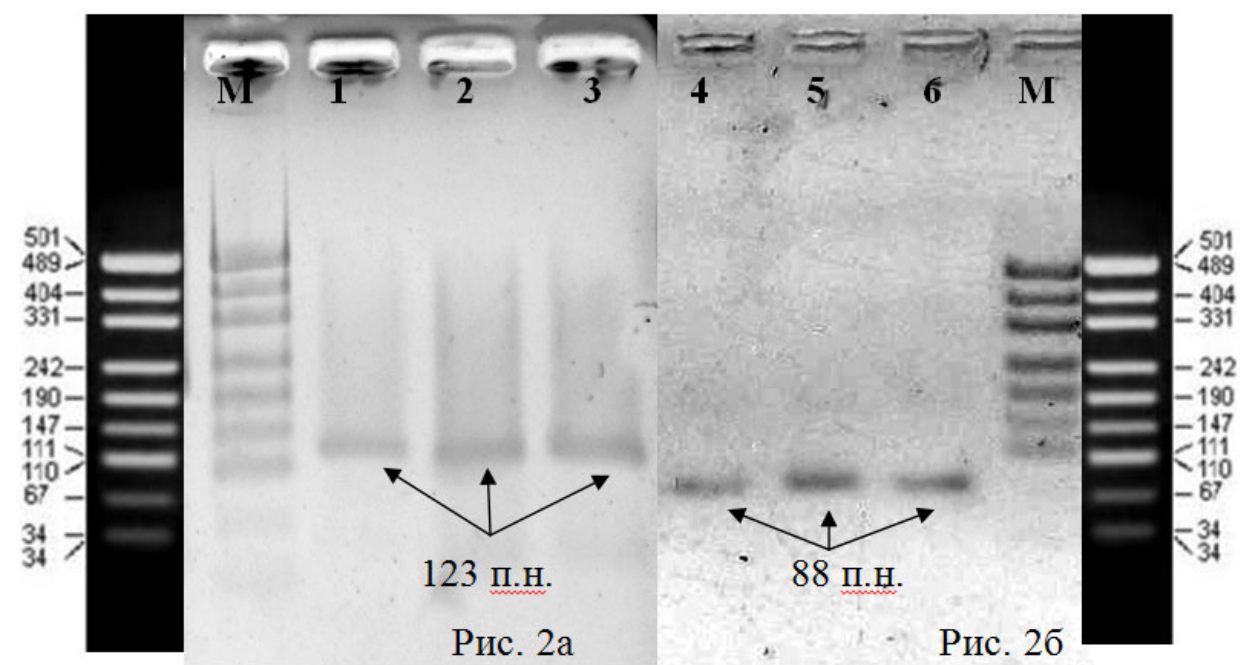

Рис. 2 а, б. Електрофареграма ампліфікації ДНК Waddlia chondrophila та Parachlamydia acanthamoebae 3 відповідніми праймерами, для визначення оптимального температурного режиму. Доріжки 1-3 ПЛР Waddlia chondrophila $55^{\circ} \mathrm{C}, 60{ }^{\circ} \mathrm{C}, 63{ }^{\circ} \mathrm{C}$; Доріжки 4-6 ПЛР Parachlamydia acanthamoebae $55^{\circ} \mathrm{C}, 60{ }^{\circ} \mathrm{C}, 63{ }^{\circ} \mathrm{C}$; $\mathrm{M}$ - маркер $p U c 19$ (Thermo Fisher Scientific)

Для оцінки специфічності праймерів використовувалася панель зразків ДНК: Waddlia chondrophila, Parachlamydia acanthamoebae, Chlamydia avium, Chlamydia pecorum, Chlamydia abortus, Chlamydia psittaci, Chlamydia suis, Chlamydia caviae,
Clavochlamydia salmonicola, Piscichlamydia salmonis. Праймери давали продукт ПЛР 123 п.н. тільки тоді, коли у зразку був присутній Waddlia chondrophila, як i очікувалося (рис. 3).

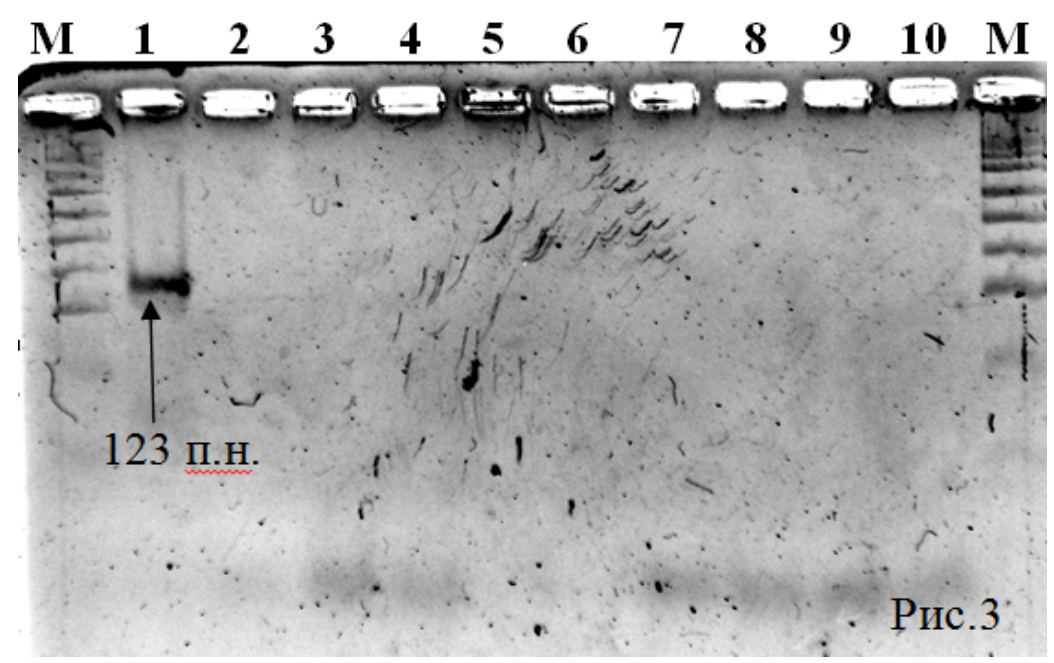

Рис. 3. Електрофареграма ампліфікації праймерів Waddlia chondrophila ДНК 10 видів бактерій порядку Chlamydiales. Доріжка 1: з ДНК Waddlia chondrophila; Доріжка 2: 3 ДНК Parachlamydia acanthamoebae; Доріжка 3: з ДНК Clavochlamydia salmonicola; Доріжка 4: з ДНК Piscichlamydia salmonis; Доріжка 1: $з$ ДНК Chlamydia avium; Доріжка 6: з ДНК Chlamydia pecorum; Доріжка 7: з ДНК Chlamydia abortus; Доріжка 8: 3 ДНК Chlamydia psittaci; Доріжка 9: з ДНК Chlamydia suis; Доріжка 10: $з$ ДНК Chlamydia caviae; М - ми використовували маркер $p U c 19$ (Thermo Fisher Scientific), як маркер довжини ДНК 
Не зважаючи на те, що існують комерційні ПЛРтести іноземного виробництва для ідентифікації цих бактерій, але в умовах нинішньої економічної ситуації в Україні широке використання цих діагностикумів практично неможливе, через високу ціну, або необхідність дорогого обладнання (для ПЛР-тестів в реальному часі). Створення простих, недорогих та доступних діагностикумів, детекції шляхом електрофорезу у гелі, могли б бути впровадженні в лабораторну практику. Тому було проведено біоінформаційні дослідженя та розроблено дизайн олігонуклеотидних праймерів, що фланкують фрагмент ділянки ДНК гену 16S pPHK, розміром 123 п.н. Waddlia chondrophila. Оптимізація ампліфікації з використанням зразків контрольних ДНК Waddlia chondrophila наданих європейськими референс-лабораторіями дозволила отримати ПЛР-продукт, що повністю відповідав очікуваному розміру 123 п.н. Специфічність праймерів була доведена відсутністю ампліфікації 3 контрольними зразками ДНК: Parachlamydia acanthamoebae, Chlamydia avium, Chlamydia pecorum, Chlamydia abortus, Chlamydia psittaci, Chlamydia suis, Chlamydia caviae, Clavochlamydia salmonicola, Piscichlamydia salmonis і в результаті отримано ПЛРтест-систему для ідентифікації і видової диференціаціï Waddlia chondrophila - хламідіє-подібного організму патогенного для сільськогосподарських тварин та людини.

\section{Висновки}

Нами було розроблено ПЛР-тест-систему для ідентифікації і видової диференціації Waddlia chondrophila.

Розроблена ПЛР тест-система для ідентифікації та видової диференціації Waddlia chondrophila після апробації на клінічному матеріалі може бути використана вченими для широкого моніторингу, використовуватись лікарями ветеринарної медицини для уточнення діагнозу, бути введеними в практику лабораторій ветеринарної медицини та гуманної медицини.

Перспективи подальших досліджень. В майбутньому можливо використання вищезазначених ПЛРтест систем у мультиплексних поєднаннях з ПЛР-тест системами для ідентифікації інших збудників інфекційних захворювань, для ідентифікації збудників і ефективного лікування.

Незначний розмір ПЛР-продукту (123 п.н.) теоретично дозволяє використовувати дану пару олігонуклеотидних праймерів і для ПЛР-тестів в реальному часі.

\section{Подяки}

Хочемо висловити свою найщирішу вдячність тим, без котрих дані дослідження були б неможливими: Ксьонзу Ігору Миколайовичу, доктору ветеринарних наук Інституту свинарства і агропромислового виробництва НААН, що не шкодував сил і часу, надихав і завжди спрямовував свій талант на досягнення успіху в нашій спільній справі. Щиро дякуємо вченим, які відгукнулися: Dr. Michel Rolf, (Central Military Hospital Koblenz, Germany, Dept. Pathology, Professeur); Gilbert GREUB - MD-PhD (Chef de Service et Directeur de l'Institut de Microbiologie Médecin chef des laboratoires de microbiologie diagnostique Institut de microbiologie de l'Université de Lausanne, Switzerland); Dr. Christiane Schnee, (Arbeitsgruppenleiterin, Institut für molekulare Pathogenese, Jena, Germany); Heike Schmidt-Posthaus, PD, Dr med vet, Dipl. ECVP, (Centre for Fish and Wildlife Health Bern) - за ту неоціненну допомогу, яку ви нам надали, в вигляді зразків контрольних ДНК, завдяки чому стало можливим виконання поставлених перед нами задач.

\section{References}

Barkallah, M., Gharbi, Y., Hassena, A.B., Slima, A.B., Mallek, Z., Gautier, M., Greub, G., Gdoura, R., \& Fendri, I. (2014). Survey of infectious etiologies of bovine abortion during mid- to late gestation in dairy herds. PloS One, 9, e91549. doi: 10.1371/journal.pone.0091549.

Baud, D., Goy, G., Osterheld, M.-C., Borel, N., Vial, Y., Pospischil, A., \& Greub, G. (2011). Waddlia chondrophila: from bovine abortion to human miscarriage. Clin. Infect. Dis. Off. Publ. Infect. Dis. Soc. Am, 52(12), 1469-1471. doi: 10.1093/cid/cir205.

Blumer, S., Greub, G., Waldvogel, A., Hässig, M., Thoma, R., Tschuor, A., Pospischil, A., \& Borel, N. (2011). Waddlia, Parachlamydia and Chlamydiaceae in bovine abortion. Vet. Microbiol, 152, 385-393. doi: 10.1016/j.vetmic.2011.05.024.

Borel, N., Ruhl, S., Casson, N., Kaiser, C., Pospischil, A., \& Greub, G. (2007). Parachlamydia spp. and Related Chlamydia-like Organisms and Bovine Abortion. Emerg. Infect. Dis., 13(12), 1904-1907. doi: 10.3201/eid1312.070655.

Burnard, D., \& Polkinghorne, A. (2016). Chlamydial infections in wildlife-conservation threats and/or reservoirs of 'spill-over' infections? Vet. Microbiol., 196, 78-84. doi: 10.1016/j.vetmic.2016.10.018.

Corsaro, D., Venditti, D., \& Valassina, M. (2002). New parachlamydial 16S rDNA phylotypes detected in human clinical samples. Res. Microbiol., 153(9), 563567. https://www.ncbi.nlm.nih.gov/pubmed/12455703.

Dilbeck, P.M., Evermann, J.F., Crawford, T.B., Ward, A.C., Leathers, C.W., Holland, C.J., Mebus, C.A., Logan, L.L., Rurangirwa, F.R., \& McGuire, T.C. (1990). Isolation of a previously undescribed rickettsia from an aborted bovine fetus. J. Clin. Microbiol., 28(4), 814-816. https://www.ncbi.nlm.nih.gov/pubmed/2185269.

Dilbeck-Robertson, P., McAllister, M.M., Bradway, D., \& Evermann, J.F. (2003). Results of a new serologic test suggest an association of Waddlia chondrophila with bovine abortion. J. Vet. Diagn. Investig. Off. Publ. Am. Assoc. Vet. Lab. Diagn. Inc, 15(6), 568569. doi: 10.1177/104063870301500609.

Goy, G., Croxatto, A., Posfay-Barbe, K.M., Gervaix, A., \& Greub, G. (2009). Development of a real-time PCR for the specific detection of Waddlia chondrophila in 
clinical samples. Eur. J. Clin. Microbiol. Infect. Dis. Off. Publ. Eur. Soc. Clin. Microbiol., 28(12), 14831486. doi: 10.1007/s10096-009-0804-7.

Greub, G., Boyadjiev, I., La Scola, B., Raoult, D., \& Martin, C. (2003). Serological hint suggesting that Parachlamydiaceae are agents of pneumonia in polytraumatized intensive care patients. Ann. N. Y. Acad. Sci., 990, 311-319. https://www.ncbi.nlm.nih.gov/pubmed/12860644.

Haider, S., Collingro, A., Walochnik, J., Wagner, M., \& Horn, M. (2008). Chlamydia-like bacteria in respiratory samples of community-acquired pneumonia patients. FEMS Microbiol. Lett. 281, 198-202. doi: 10.1111/j.1574-6968.2008.01099.x.

Ks'onz, I.M. (2012). Hlamidiozy tvaryn: monografija, 1st ed. Orijana, Poltava (in Ukrainian).

Taylor-Brown, A., Vaughan, L., Greub, G., Timms, P., \& Polkinghorne, A. (2015). Twenty years of research in- to Chlamydia-like organisms: a revolution in our understanding of the biology and pathogenicity of members of the phylum Chlamydiae. Pathog. Dis., 73, 115. doi: 10.1093/femspd/ftu009.

Zezekalo, V.K., Peredera, S.B., Buslik, T.V., \& Pochernyaev, K.F. (2018). PCR-test system specific identification Parachlamydia acanthamoebae. Scientific Messenger of Lviv National University of Veterinary Medicine and Biotechnologies, 20(92), 101-104. doi: 10.32718/nvlvet9220 (in Ukrainian).

Zezekalo, V.K., Peredera, S.B., \& Shherbakova, N.S. (2019). Onovlennja taksonomichnoi' klasyfikacii' mikroorganizmiv porjadku Chlamydiales. Visnyk Poltavs'koi' derzhavnoi' agrarnoi' akademii', 1(24), 207216 (in Ukrainian). 